\title{
Peningkatan kreativitas seni anak melalui kolase dengan menggunakan daun pisang di TK Aisyiyah Talaok
}

\author{
Ahem Kasta \\ TK Aisyiyah Talaok Kecamatan Bayang
}

\begin{abstract}
Abstrak
Kreativitas merupakan pengalaman dalam mengekpresikan dan mengaktualisasikan indentitas individu dalam bentuk terpadu antara hubungan diri sendiri, alam dan orang lain. Hal ini jelas bahwa kreativitas terbentuk karena adanya rangsangan yang diberikan oleh lingkungannya. Tanpa ada rangsangan maka akan sulit tercipta sebuah kreativitas. Perkembangan kreativitas seni anak di TK Aisyiyah Talaok Kecamatan Bayang Kabupaten Pesisir Selatanbelum berkembang secara optimal, strategi pembelajaran yang diterapkan guru belum mampu mengembangkan kreativitas seni anak, teknik memupuk kreativitas seni yang digunakan belumsesuai dengan tujuan pembelajaran yang diharapkan, kurangnya media yang digunakan oleh guru, evaluasi pembelajaran belum optimal dalam melihat hasil pembelajaran. Metode kolase terbukti dapat meningkatkan kemampuan kreatifitas anak dalam kegiatan seni. Anak dapat mengenal teknik kolase dengan berbagai media, menempel dengan berbagai media sesuai dengan pola guru, dan menempel dengan berbagai media dengan rapi.Kegiatan ini dapat melatih imajinasi, melatih membuat irama, melatih rasa kebersamaan melalui kerja kelompok, dan meningkatkan untuk mengutarakan pendapat, meningkatkan apresiasi ide-ide baru dan lain sebagainya.
\end{abstract}

Keywords: Kreativitas seni, kolase

\section{PENDAHULUAN}

Pendidikan taman kanak-kanak adalah salah satu bentuk pendidikan anak usia dini yang berada pada jalur pendidikan yang bertujuan untuk membantu meletakkan pada dasar pertama dalam pengembangan seluruh potensi dan kemampuan fisik, intelektual, emosional, moral dan agama secara optimal dalam lingkungan yang kondusif, demokratis, dan kompetitif. Sehubungan hal tersebut didalam Kurikulum KTSP 2006 dan juga Kurikulum 2013, bahwa ruang lingkup pengembangan pembelajaran TK dibagi kedalam bidang pengembangan pembiasaan dan bidang pengembangan kemampuan dasar. Bidang pengembangan pembiasaan merupakan kegiatan yang dilakukan secara terus menerus dalam kehidupan sehari-hari, sehingga menjadi kebiasaan yang baik. Sedangkan bidang pengembangan kemampuan dasar merupakan kegiatan yang dipersiapkan guru untuk meningkatkan kemampuan dan kreativitas dengan pengembangan.

Sesuai dengan apa yang telah tertuang dalam PP No. 19 thn 2005 pasal 19 ayat 1 yang berbunyi "Proses pembelajaran pada satuan pendidikan diselenggarakan secara interaktif, inspiratif, menyenangkan, menantang, memotivasi peserta didik untuk berpartisipasi aktif, serta memberikan ruang yang cukup bagi prakarsa, kreativitas, dan kemandirian sesuai dengan bakat, minat, dan perkembangan fisik serta psikologis peserta didik (PP N0.19 thn 2005 pasal 19 ayat 1)”. 
Dalam hal ini pendidikan anak usia dini adalah pendidikan yang dilaksanakan pada masa usia dini. Masa usia dini adalah masa peka, karena pada masa ini anak sangat sentitif dan sangat peka terhadap sesuatu yang ada di sekitarnya. Sehingga pada masa ini merupakan saat yang paling tepat bagi anak menerima respons atau rangsangan-rangsangan yang diberikan oleh lingkungannya. Dengan demikian, lingkungan sebagai unsur yang menyediakan sejumlah rangsangan perlu mendapatkan perhatian dan perlu diciptakan sedemikian rupa, agar menyediakan objek-objek sesuai dengan kebutuhan dan perkembangan anak. Untuk itu perlu perencanaan yang matang. Ketepatan lingkungan belejar secara langsung dan tidak langsung akan sangat mempengaruhi proses dan hasil belajar yang akan dicapai anak.

Kreativitas merupakan pengalaman dalam mengekpresikan dan mengaktualisasikan indentitas individu dalam bentuk terpadu antara hubungan diri sendiri, alam dan orang lain. Hal ini jelas bahwa kreativitas terbentuk karena adanya rangsangan yang diberikan oleh lingkungannya. Tanpa ada rangsangan maka akan sulit tercipta sebuah kreativitas.

Seni adalah suatu yang menghasilkan kesenangan atau merupakan kegiatan sadar manusia dengan perantaraan tanda-tanda lahirian tertentu untuk menyampaikan perasaan yang telah dihayati kepada orang lain atau benda. Selain itu seni merupakan hasil atau proses kerja dan gagasan manusia yang melibatkan kemampuan terampil, kreatif, kepekaan indera, kepekaan hati dan ikiran untuk menghasilkan suatu karya yang memiliki kesan keindahan, keselarasan, bernilai seni dan lainnya.

Pada Taman Kanak-kanak kreativitas seni anak dapat berkembang dengan baik, salah satunya melalui kegiatan kolase. Hal ini sesuai dengan pendapat Hajar Pamadhi dan Sukardi (2008:5,26), bahwa Kolase adalah memadukan barang-barang yang terdiri dari benda yang berbeda-beda hingga menjadi sebuah karya melalui tehnik assembling (dengan dilem, dipadu dan lain-lain) dimaksudkan agar dapat menyatu. Dalam kegiatan pembelajaran di TK maka kreativitas seni dengan kolase adalah kegiatan berlatih karya seni rupa yang dilakukan dengan cara mengisi bagian-bagian yang dapat dibuat benda hiasan tulis dengan memakai bantuan alat sesuai tingkat kemampuan anak. Selain itu kegiatan dan kreativitas-kreativitas seni jarang diterapkan guru di TK.

Padahal keterampilan dan kreativitas dalam kegiatan dalam kelas sangat bermanfaat untuk merangsang kreativitas anak. Untuk itu kegiatan kolase harus terus ditingkatkan untuk mengembangkan kreativitas seni yang dimiliki oleh setiap anak khususnya pada masa usia dini.

Dalam kegiatan pembelajaran di TK maka Kreativitas seni dengan Kolase adalah kegiatan berlatih berkarya senirupa yang dilakukan dengan cara menyusun bagian-bagian bahan yang sapat dibuat benda hias atau benda pakai dengan memakai bantuan alat rangkai sesuai tingkat kemampuan anak.

Berdasarkan observasi awal di TK Aisyiyah Talaok Kecamatan bayang Kabupaten Pesisir Selatanditemukan bahwa proses pembelajaran kreativitas seni masih belum berkembang sesuai dengan yang diharapkan. Beberapa fenomena yang dapat dijadikan indikator permasalahan tersebut sebagai berikut : Perkembangan kreativitas seni anak di TK Aisyiyah Talaok Kecamatan Bayang Kabupaten Pesisir Selatanbelum berkembang secara optimal, strategi pembelajaran yang diterapkan guru belum mampu mengembangkan kreativitas seni anak, teknik memupuk kreativitas seni yang digunakan belumsesuai dengan tujuan pembelajaran yang diharapkan, kurangnya media yang digunakan oleh guru, evaluasi pembelajaran belum optimal dalam melihat hasil pembelajaran.

Melihat fenomena tersebut, maka peneliti tertarik melakukan penelitian tindakan kelas dengan judul "Peningkatkan Kreativitas Seni Anak melalui Kolase dengan Menggunakan Daun Pisang di TK Aisyiyah Talaok Kecamatan Bayang Kabupaten Pesisir Selatan”.

\section{METODE}

Penelitian adalah Penelitian Tindakan Kelas (PTK). PTK menurut Arikunto (2006) adalah merupakan suatu pencermatan terhadap kegiatan belajar yang berupa sebuah tindakan yang sengaja dimunculkan dan terjadi dalam kelas secara bersama. Subjek penelitian ini adalah anak didik pada kelompok B I di TK Aisyiyah Talaok Kecamatan Bayang Kabupaten Pesisir Selatan Kabupaten Pesisir Selatan dengan jumlah anak sebanyak 17 orang, terdiri dari anak laki-laki 9 orang dan anak perempuan 8 orang.

Prosedur penelitian dilaksanakan secara bersiklus, mulai dari Siklus I. Menurut Arikunto (2006) PTK dilaksanakan dengan rangkaian kegiatan terbentuk siklus yang melalui empat tahapanyaitu Perencanaan, 
Pelaksanaan, Pengamatan dan Refleksi. Instrumen dalam penelitian ini adalah dengan mengamati anak melalui kegiatan kolase dengan menggunakan daun pisang dengan menggunakan format observasi. Pedoman observasi untuk mengecek kegiatan yang dilakukan berdasarkan indikator yang digunakan dan aspek yang diamati dan ditulis dalam embaran observasi

Berdasarkan sumber data yang tertulis diatas maka teknikdan alat pengumpul data melalui, data yang diperoleh dari kegiatan yang diamati selama proses kegiatan berlangsung yang hasilditulis dalam lembar observasi, melakukan dokumentasi saat kegiatan berlangsung.Data yang diperoleh selama penelitian berlangsung dianaliusis dengan teknikpersentase, yaitu membandingkan yang muncul dari keseluruhan anak yang hadir dikalikan 100\%. Untuk melihat kecendrungan data, data di tampilkan dalam bentuk tabel dan diolah secara deskriptif.

Keberhasilan miningkatkan keberhasilan kreatifitas anak melalui kolase dengan daun pisang ditandai oleh beberapa hal dengan memakai rumus Alwen Bentri (2005) seperti berikut ini: 1) 75\% anak tertarik pada kolase dengan daun pisang; 2) 75\% anak mampu melakukan kreatifitas pada kolase dengan daun pisang.

\section{HASIL PENELITIAN DAN PEMBAHASAN}

\section{Deskripsi Kondisi Awal}

Berdasarkan pengamatan pada kondisi awal penelitian di TK Aisyiyah Talaok Kecamatan Bayang Kabupaten Pesisir Selatan Kelompok B1, peneliti menemukan kreatifitas seni anak belum berkembang baik. Hal itu tampak dalam hasil observasi menunjukkan kreatifitas seni belum berkembang optimal, diantaranya masih ada beberapa anak yang tidak mampu mengerjakan apa yang ditugaskan kepadanya dan masih tergantung dengan contoh atau media yang diberikan guru. Hal ini terlihat dari sebagian anak mengalami kesulitan ketika mengerjakan tugasnya. Untuk lebih jelasnya dapat dilihat pada tabel dan grafik dibawah ini :

Tabel 1. Hasil Observasi Peningkatan Kreatifitas Seni Anak Melalui Kegiatan Kolase pada Kondisi Awal (sebelum tindakan)

\begin{tabular}{|c|c|c|c|c|c|c|c|c|c|}
\hline \multirow[t]{2}{*}{ No } & \multirow[t]{2}{*}{ Aspek yang dinilai } & \multicolumn{8}{|c|}{ Jumlah 17 anak } \\
\hline & & $\overline{\mathrm{AB}}$ & $\%$ & $\bar{B}$ & $\%$ & $\overline{\mathrm{C}}$ & $\%$ & $\mathrm{R}$ & $\%$ \\
\hline 1 & Anak mampu melukis dengan berbagai bentuk & - & 0 & 4 & 24 & 6 & 35 & 7 & 41 \\
\hline 2 & $\begin{array}{l}\text { Anak mampu menempel dengan berbagai } \\
\text { media sesuai dengan pola }\end{array}$ & - & 0 & 1 & 6 & 5 & 29 & 11 & 65 \\
\hline 3 & $\begin{array}{l}\text { Anak mampu menempel dengan berbagai } \\
\text { media dengan rapi }\end{array}$ & - & 0 & 1 & 6 & 4 & 24 & 12 & 71 \\
\hline & Nilai rata-rata & - & 0 & & 12 & & 29 & & 59 \\
\hline
\end{tabular}

\section{Deskripsi Siklus I}

Pelaksanaan kegiatan pembelajaran peningkatan kreatifitas seni anak melalui kolase dengan daun pisang pada anak TK Aisyiyah Talaok Kecamatan Bayang Kabupaten Pesisir Selatan siklus I sudah sesuai dengan yang direncanakan, berdasarkan hasil pengamatan yang telah peneliti lakukan terlihat bahwa: 1) Meningkatnya kreatifitas seni anak melalui kolase dengan daun pisang bila dibandingkan dengan kondisi awal, maka pada Siklus I dari Pertemuan 1 sampai Pertemuan 3 dengan 3 aspek yang diamati terlihat pada setiap pertemuan menunjukkan peningkatan yang cukup berarti; 2) Rata-rata peningkatan kreatifitas seni anak dari Pertemuan 1 sebesar 18\%, pada Pertemuan 2 sebesar 29\% dan pada Pertemuan 3 meningkat menjadi 35\%; 3) Ditinjau dari aktivitas guru pembelajaran pada Siklus I telah berjalan dengan baik dan berhasil, dan ada pula hal-hal yang perlu diperhatikan guru yaitu masih ada anak yang kurang antusias dan kurang percaya diri dalam mengikuti pembelajaran peningkatan kreatifitas seni anak melalui kolase dengan daun pisang.

Untuk mengatasi hal di atas dilakukan hal-hal sebagai berikut : 1) Memberi motivasi dan membimbing anak terutama pada anak yang kurang percaya diri; 2) Mendampingi anak secara individual terutama bagi anak yang masih mengalami kesulitan dengan media yang digunakan; 3) Merancang pembelajaran dengan memperhatikan kondisi anak dengan cara memindahkan kegiatan pembelajaran yang dilakukan sebelum anak-anak istirahat dan bermain di luar.

Berdasarkan hasil pengamatan dari peningkatan kreatifitas seni anak melalui kolase dengan daun pisang Siklus I dapat dideskripsikan sebagai berikut : Aspek anak yang mampu mengerjakan kolase dengan media daun pisang pada Siklus I pada Pertemuan 1 dalam kategori baik 35\%, kategori cukup 29\% dan kategori rendah $35 \%$. 
Pada Pertemuan 2 dalam kategori baik 41\%, kategori cukup 24\% dan kategori rendah 35\%. Pada Pertemuan 3 dalam kategori baik 53\%, kategori cukup 29\% dan kategori rendah 18\%. Dari aspek pertama dilihat peningkatan yang baik dari Pertemuan 1 sampai Pertemuan 3 pada kategori yang dinilai dalam peningkatan kreatifitas seni anak dari kolase dengan daun pisang.

Aspek anak yang mampu menempel dengan daun pisang sesuai dengan pola pada siklus I Pada Pertemuan 1 dalam kategori baik 12\%, kategori cukup 24\% dan kategori rendah 65\%. Pada Pertemuan 2 dalam kategori baik 24\%, kategori cukup 24\% dan kategori rendah 53\%. Pada Pertemuan 3 dalam kategori baik 30\%, kategori cukup $24 \%$ dan kategori rendah $47 \%$.

Tabel 2. Rekapitulasi Hasil Observasi Peningkatan Kreatifitas Seni Anak melalui Kolase dengan Daun Pisang Siklus I Pertemuan I, 2, 3 (setelah tindakan)

\begin{tabular}{|c|c|c|c|c|c|c|c|c|c|c|c|c|c|c|c|c|c|c|c|c|c|c|c|c|c|}
\hline \multirow[t]{2}{*}{ No } & \multirow[t]{2}{*}{$\begin{array}{c}\text { Aspek Yang } \\
\text { dinilai }\end{array}$} & \multicolumn{8}{|c|}{$\begin{array}{c}\text { Pertemuan I } \\
\text { Jumlah } 17 \text { anak }\end{array}$} & \multicolumn{8}{|c|}{$\begin{array}{c}\text { Pertemuan II } \\
\text { Jumlah } 17 \text { anak }\end{array}$} & \multicolumn{8}{|c|}{$\begin{array}{c}\text { Pertemuan III } \\
\text { Jumlah } 17 \text { anak }\end{array}$} \\
\hline & & $\overline{\mathrm{AB}}$ & $\%$ & B & $\%$ & $\mathrm{C}$ & $\%$ & $\mathrm{R}$ & $\%$ & $\overline{\mathrm{AB}}$ & $\%$ & B & $\%$ & $\mathrm{C}$ & $\%$ & $\bar{R}$ & $\%$ & $\overline{\mathrm{AB}}$ & $\%$ & B & $\%$ & $\mathrm{C}$ & $\%$ & $\overline{\mathrm{R}}$ & $\%$ \\
\hline 1 & $\begin{array}{l}\text { Anak mampu } \\
\text { mengerjakan } \\
\text { kolase dengan } \\
\text { media daun } \\
\text { pisang }\end{array}$ & - & 0 & 6 & 35 & 5 & 29 & 6 & 35 & - & 0 & 7 & 41 & 4 & 24 & 6 & 35 & - & 0 & 9 & 53 & 5 & 29 & 3 & 18 \\
\hline 2 & $\begin{array}{l}\text { Anak mampu } \\
\text { menempel } \\
\text { dengan daun } \\
\text { pisang sesuai } \\
\text { dengan pola }\end{array}$ & - & 0 & 2 & 12 & 4 & 24 & 11 & 65 & - & 0 & 4 & 24 & 4 & 24 & 9 & 53 & - & 0 & 5 & 30 & 4 & 24 & 8 & 47 \\
\hline 3 & $\begin{array}{l}\text { Anak mampu } \\
\text { menempel } \\
\text { dengan daun } \\
\text { pisang dengan } \\
\text { rapi }\end{array}$ & - & 0 & 1 & 6 & 3 & 18 & 13 & 76 & - & 0 & 4 & 24 & 4 & 24 & 9 & 53 & - & 0 & 4 & 24 & 6 & 35 & 7 & 41 \\
\hline & Nilai rata-rata & - & 0 & 3 & 18 & 4 & 24 & 10 & 59 & - & 0 & 5 & 29 & 4 & 24 & 8 & 47 & - & 0 & 6 & 35 & 5 & 29 & 6 & 35 \\
\hline
\end{tabular}

Dari aspek kedua ini terlihat peningkatan yang baik dari pertemuan 1 sampai pertemuan 3 pada kategori yang dinilai dalam peningkatan kreatifitas seni anak melalui kolase dengan daun pisang. Aspek anak yang mampu menempel dengan daun pisang dengan rapi. pada siklus I. Pada Pertemuan 1 dalam kategori baik 6\%, kategori cukup 18\% dan kategori rendah 76\%. Pada Pertemuan 2 dalam kategori baik 24\%, kategori cukup 24\% dan kategori rendah 53\%. Pada Pertemuan 3 dalam kategori baik 24\%, kategori cukup 35\% dan kategori rendah $41 \%$.

Dari aspek ini terlihat peningkatan yang baik dari Pertemuan 1 sampai Pertemuan 3 pada kategori yang dinilai dalam peningkatan kreatifitas seni anak melalui kolase dengan daun pisang. Berdasarkan tabel diatas persentase rata-rata siklus I Pertemuan I, 2, 3 adalah sebagai berikut : pada siklus I pada Pertemuan 1 rata-rata kategori baik $18 \%$ pada kategori cukup 24\% dan kategori rendah 59\%. Pertemuan 2 rata-rata kategori baik $29 \%$ pada kategori cukup 24\% dan kategori rendah 47\%. Pada Pertemuan 3 rata-rata kategori baik 35\% pada kategori cukup $29 \%$ dan kategori rendah $35 \%$.

\section{Siklus II}

Mencermati hasil yang diperoleh pada Siklus I yang belum memuaskan, maka kegiatan penelitian dilanjutkan pada Siklus II. Perencanaan kegiatan peningkatan kreatifitas seni anak melalui kolase dengan daun pisang pada anak TK Aisyiyah Talaok Kecamatan Bayang Kabupaten Pesisir Selatan pada Siklus II dilakukan pada hari Senen, 19 Februari 2018. Yaitu setelah selesai dilakukannya Siklus I. Siklus II juga dilaksanakan 3 x pertemuan. Pertemuan 1 dilaksanakan pada hari Senen, 19 Februari 2018, pertemuan 2 pada hari Sabtu, 24 Februari 2018 dan Pertemuan 3 pada hari Sabtu, 03 Maret 2018.

Pelaksanaan kegiatan pembelajaran peningkatan kreatifitas seni anak melalui kolase dengan daun pisang pada anak TK Aisyiyah Talaok Kecamatan Bayang Kabupaten Pesisir Selatan siklus II sudah sesuai dengan yang direncanakan, berdasarkan hasil pengamatan yang telah peneliti lakukan terlihat bahwa:

1. Peningkatan kreatifitas seni anak melalui kolase dengan daun pisang pada Siklus II bila dibandingkan dengan Siklus I terlihat secara keseluruhan pada setiap pertemuan menunjukkan peningkatan yang cukup berarti dan sesuai dengan kriteria keberhasilan yang direncanakan.

2. Rata-rata peningkatan kreatifitas seni anak dari pada siklus I sebesar $47 \%$, meningkat menjadi $71 \%$. Hal ini menunjukkan adanya peningkatan menjadi $82 \%$. 
3. Hasil pelaksanaan pembelajaran kolase dengan daun pisang pada anak TK Aisyiyah Talaok Kecamatan Bayang Kabupaten Pesisir Selatan pada Siklus II sebesar 71\% sesuai dengan kriteria keberhasilan yang ditetapkan. Dengan demikian pada penelitian dihentikan dan tidak dilanjutkan pada siklus berikutnya.

Tabel 3. Rekapitulasi Hasil Observasi Peningkatan Kreatifitas Seni Anak melalui Kolase dengan Daun PisangSiklus II Pertemuan I, 2, 3 (setelah tindakan)

\begin{tabular}{|c|c|c|c|c|c|c|c|c|c|c|c|c|c|c|c|c|c|c|c|c|c|c|c|c|c|}
\hline \multirow[t]{2}{*}{ No } & \multirow[t]{2}{*}{$\begin{array}{c}\text { Aspek Yang } \\
\text { dinilai }\end{array}$} & \multicolumn{8}{|c|}{$\begin{array}{c}\text { Pertemuan I } \\
\text { Jumlah } 17 \text { anak }\end{array}$} & \multicolumn{8}{|c|}{$\begin{array}{c}\text { Pertemuan II } \\
\text { Jumlah } 17 \text { anak }\end{array}$} & \multicolumn{8}{|c|}{$\begin{array}{c}\text { Pertemuan III } \\
\text { Jumlah } 17 \text { anak }\end{array}$} \\
\hline & & $\mathrm{AB}$ & $\%$ & B & $\%$ & $\mathrm{C}$ & $\%$ & $\mathrm{R}$ & $\%$ & $\overline{\mathrm{AB}}$ & $\%$ & B & $\%$ & $\mathrm{C}$ & $\%$ & $\bar{R}$ & $\%$ & $\mathrm{AB}$ & $\%$ & B & $\%$ & $\mathrm{C}$ & $\%$ & $\mathrm{R}$ & $\%$ \\
\hline 1 & $\begin{array}{l}\text { Anak mampu } \\
\text { mengerjakan } \\
\text { kolase dengan } \\
\text { media daun } \\
\text { pisang }\end{array}$ & 1 & 6 & 8 & 47 & 4 & 24 & 4 & 24 & 3 & 18 & 7 & 41 & 4 & 24 & 3 & 18 & 6 & 35 & 7 & 41 & 2 & 12 & 2 & 12 \\
\hline 2 & $\begin{array}{l}\text { Anak mampu } \\
\text { menempel } \\
\text { dengan daun } \\
\text { pisang sesuai } \\
\text { dengan pola }\end{array}$ & 1 & 6 & 6 & 35 & 5 & 29 & 5 & 29 & 5 & 29 & 8 & 47 & 2 & 12 & 2 & 12 & 7 & 41 & 8 & 47 & 1 & 6 & 1 & 6 \\
\hline 3 & $\begin{array}{l}\text { Anak mampu } \\
\text { menempel } \\
\text { dengan daun } \\
\text { pisang dengan } \\
\text { rapi }\end{array}$ & 1 & 6 & 7 & 41 & 6 & 35 & 3 & 18 & 4 & 24 & 9 & 53 & 3 & 18 & 1 & 6 & 8 & 47 & 6 & 35 & 3 & 18 & 0 & 0 \\
\hline & Nilai rata-rata & 1 & 6 & 7 & 41 & 5 & 29 & 4 & 24 & 4 & 24 & 8 & 47 & 3 & 18 & 2 & 12 & 7 & 41 & 7 & 41 & 2 & 12 & 1 & 6 \\
\hline
\end{tabular}

\section{PEMBAHASAN}

Pada tahap awal kegiatan (sebelum tindakan) dalam penelitian kemampuan anak dalam kegiatan kolase dengan berbagai media, menempel dengan berbagai sesuai dengan pola guru dan, kegiatan menempel dengan berbagai media dengan rapimasih rendah, berarti anak belum mampu kolase dengan berbagai media, menempel dengan berbagai sesuai dengan pola guru dan, kegiatan menempel dengan berbagai media dengan rapi. Pada tahap awal sebelum tindakan ini pada kegiatan pembelajaran masih rendah, anak tidak bersemangat dan kelihatan jenuh dalam melaksanakan kegiatan.

Pada Siklus I setelah dilakukan kegiatan pembelajaran (setelah tindakan) terlihat bahwa terjadi peningkatan kreatifitas anak dalam kegiatan kolase dengan menggunakan daun pisang dengan mencontoh pola guru, ini terlihat pada hasil observasi yang telah peneliti lakukan sebanyak 3 pertemuan dan hasilnya kurang memuaskan maka peneliti lanjutkan dengan Siklus II.

Dengan menggunakan metode kolase ini dapat meningkatkan kreatifitas seni anak, terlihat terjadinya peningkatan kreatifitas seni anak. Hal ini dikuatkan oleh Sumanto (2000) Kreatifitas merupakan salah satu bantuan pokok manusia yaitu kebutuhan yang paling tinggi manusia untuk upaya mendidik kecerdasan ganda dan memberikan pengalaman berolah cipta seni dengan menggunakan berbagai media rupa sesuai tingkat kemampuan anak.

Pada siklus kedua ini peneliti mulai memberikan kegiatan kolase dengan menggunakan daun pisang dengan membagi anak menjadi dua kelompok sehingga dengan adanya pembagian kelompok ini peneliti lebih mudah untuk membimbing dan membina anak.

Sementara itu Lowenfeld dalam Sumanto (2005) kreatifitas adalah seperangkat kemampuan seseorang meliputi kepekaan mengamati berbagai masalah melalui indra kelancaran mengeluarkan berbagai alternatif pemecahan masa keluwesan melihat atau memandang suatu masalah serta kemungkinan dalam pemecahan masalah. Sedangkan menurut Pamadhi (2010) kolase merupakan karya seni dua dimensi yang menggunakan bahan bermacam-macam selama bahan dasar tersebut dapat dipadukan dengan bahan dasar lain yang akhirnya dapat menyatu menjadi karya yang utuh dan dapat mewakili ungkapan perasaan estetis orang yang membuatnya.

Dapat disimpulkan bahwa kreatifitas merupakan suatu proses mental indicidu yang melahirkan gagasan, proses, metoda ataupun produk baru yang efektif yang bersifat imajinatif yang berdaya guna dlam berbagai bidang untuk memecahkan suatu masalah sedangkan seni adalah kegiatan dalam mengekspresikan pengalaman hidup dan kesadaran hasil pemikiran dan perasaan anak tentang diri dan lingkungan sekitar. Dengan menggunakan metode kolase ini terbukti dapat meningkatkan kemampuan kreatifitas anak dalam kegiatan seni. Anak dapat mengenal teknik kolase dengan berbagai media, menempel dengan berbagai media sesuai dengan pola guru, dan menempel dengan berbagai media dengan rapi. Dalam kegiatan ini diharapkan dapat melatih 
imajinasi, melatih membuat irama, melatih rasa kebersamaan melalui kerja kelompok, dan meningkatkan untuk mengutarakan pendapat, meningkatkan apresiasi ide-ide baru dan lain sebagainya.

\section{KESIMPULAN}

Berdasarkan hasil penelitian dan pembahasan yang telah diuraikan pada bab sebelumnya, maka sesuai dengan tujuan penelitian dapat diambil kesimpulan sebagai berikut : 1) Kegiatan kolase dengan menggunakan daun pisang dapat meningkatkan kreatifitas seni di TK AisyiyahTalaokKecamatanBayangKabupatenPesisir Selatan Pesisir Selatan; 2) Kreatifitas seni anak dalam melakukan kolase menunjukkan peningkatan yang cukup berarti. Melalui kolase dapat mengembangkan kreatifitas atau pengembangan kemampuan berfikir kreatif anak; 3) Pelaksanaan kegiatan pembelajaran peningkatan kreatifitas seni anak melalui kolase dengan daun pisang dilaksanakan pada anak TK Aisyiyah Talaok Kecamatan Bayang Kabupaten Pesisir Selatan Bayangyang dilakukan dua siklus penelitian; 4) Setelah dilaksanakan kegiatan pembelajaran peningkatan kreatifitas seni anak melalui kolase dengan daun pisang ternyata terbukti dapat meningkatkan mengerjakan kolase dengan daun pisang hal ini dapat dilihat dari hasil yang diperoleh pada siklus I dan II yang terus mengalami peningkatan. 5) Hasil yang diperoleh dari hasil pelaksanaan kegiatan pembelajaran peningkatan kreatifitas seni anak melalui kolase dengan daun pisang pada kondisi awal sebesar $12 \%$, pada siklus I meningkat menjadi $27 \%$ dan pada siklus II meningkat menjadi $67 \%$ anak yang sudah mengerjakan kolase.

\section{DAFTAR RUJUKAN}

Departemen Pendidikan Nasional. (2005). Pedoman Pembelajaran di Taman Kanak-Kanak. Jakarta: Departemen Pendidikan Nasional Direktorat Jendral Manajemen Pendidikan Dasar dan Menengah.

Elis Kurniati. (2005). Strategi Pengembangan Kreatifitas Anak di TK. Jakarta: Depdiknas.

FitriaWita. (2007). Permaiana Kolase untuk Meningkatkan Kreatifitas Anak di TK Kartika.Lapai, Padang.

Masitoh, dkk. (2006). Strategi Pembelajaran TK. Jakarta: Universitas Terbuka.

Rachmawati, Yeni dan Euis Kurniati. (2010). Strategi Pengembangan Kreatifitas pada Anak Usia TK. Jakarta: Kencana

Santoso, Soegeng. (2005). Dasar-Dasar Pendidikan TK. Jakarta: Universitas Terbuka.

Semiawan. (2002). Belajardan Pembelajaran dalam Taraf Usia dini. Jakarta: Frendhalindo.

SitiAisyah. (2008). Perkembagan dan Konsep dasar Pengembangan AUD. Jakarta: Universitas terbuka.

Sumanto. (2005. Pengembangan Kreatifitas Seni Rupa Anak TK. Jakarta: Departemen Pendidikan Nasional.

Pamadhi Hajar dan Evan Sukardi.S (2010). Seni Keterampilan Anak. Jakarta: Universitas Terbuka.

Pekerti Widia,dkk. (2007). Metode Pengembangan Seni. Jakarta: Universitas Terbuka.

PuspitaDewi. (2009). Upaya Peningkatan Kreatifitas Anak Usia Dini Melalui Kolase Dengan Bahan Sisa Kulit Kuaci di TK Dharmawanita. Koto Gadang. 